\title{
ZMIANA PRAWA WYBORCZEGO NA URZĄD PREZYDENTA W TURCJI - POSTĘP W PROCESIE DEMOKRATYZACJI?
}

\section{Wstęp}

W Republice Turcji wybór prezydenta państwa dokonywany był po II wojnie światowej, zgodnie z kolejnymi konstytucjami z 1924 r., 1961 r. i 1982 r., przez członków tureckiego parlamentu - Wielkiego Zgromadzenia Narodowego Turcji. Taki sposób wyłaniania głowy państwa wpisywał się w funkcjonujący w tym ustroju politycznym system parlamentarny. Powszechne głosowanie miało miejsce tylko w przypadku Kenana Evrena, ale wynikało ono ze specyficznej sytuacji, która nastąpiła po zamachu stanu w 1980 r. Następni prezydenci Turcji byli już wybierani z powrotem przez parlament. ${ }^{1}$

Jednak poprawki do tureckiej ustawy zasadniczej, zaakceptowane najpierw przez parlament (10 maja 2007 r.), a później przez obywateli w referendum (21 października 2007 r.) umożliwiły przyjęcie ordynacji wyborczej dotyczącej elekcji prezydenta, która weszła w życie dnia 26 stycznia 2012 r. $^{2}$ Najważniejszym elementem tej zmiany było wprowadzenie powszechnych wyborów prezydenckich. Dnia 10 sierpnia 2014 r. obywatele tureccy wybrali w pierwszej turze na urząd prezydenta Recepa Tayyipa Erdoğana - lidera rządzącej samodzielnie od 2002 r. Partii Sprawiedliwości i Rozwoju (AKP, Adalet ve Kalkınma Partisi). ${ }^{3}$

W literaturze przedmiotu wskazuje się na to, że wybory powszechne prezydenta „dostarczają głowie państwa niezależnej i demokratycznej legitymacji, chroniąc ją skutecznie przed zdominowaniem przez parlament i partie polityczne". ${ }^{4}$ Jednym słowem, przyczyniają się one do postępów w demokratycznej konsolidacji, gdyż dają

1 A. Szymański, System konstytucyjny Turcji, Warszawa 2006, s. 5-15 i 54.

2 Cumhurbaşkanı Seçimi Kanunu, Kanun No. 6271, Kabul Tarihi 19/1/2012 (Resmi Gazete, 26 Ocak 2012, No. 28185), http://ilo.org/dyn/natlex/docs/SERIAL/91819/106649/F1826753979/91819.pdf (data dostępu: 12.02.2015 r.).

3 Erdoğan uzyskał 51,79\% głosów. Dane za: Yüksek Seçim Kurulu, www.ysk.gov.tr/ysk/content/conn/ YSKUCM/ path/Contribution\%20Folders/HaberDosya/2014CB-Gecici-416_d_Genel.pdf (data dostępu: 30.09.2014 r.).

4 A. Pułło, System prezydencki, (w:) M. Domagała (red.), Konstytucyjne systemy rządów, Warszawa 1997, s. 73. 
obywatelom prawo do wyboru kolejnego podstawowego organu w państwie oraz wzmacniają (realny) podział władz i niezależność parlamentu w wypełnianiu funkcji ustawodawczej i kontrolnej. Jednak jednocześnie podkreśla się, że takie rozwiązanie może okazać się dysfunkcjonalne dla demokratycznego charakteru systemu politycznego, jeśli w tym systemie zabraknie pewnych elementów równoważących to wzmocnienie jednego z głównych organów władzy wykonawczej. Chodzi w tym kontekście o pewne ogólne uwarunkowania (polityczne, społeczne czy gospodarcze) sprzyjające demokracji oraz konkretne rozwiązania ustrojowe, do których należą: federalizm oraz efektywne działanie zasad podziału władz i kontroli sądowej. ${ }^{5}$

Celem niniejszego artykułu jest odpowiedź na pytanie, czy przyjęcie nowego prawa wyborczego, w tym wprowadzenie powszechnych wyborów prezydenta, przyczyni się do demokratyzacji państwa czy też, wprost przeciwnie, będzie stanowić uwarunkowanie dla rozwoju tendencji autorytarnych, widocznych w Turcji (ponownie) w kilku ostatnich latach. Autor będzie w niniejszym tekście weryfikował hipotezę, że nowe przepisy, pomimo wzmocnienia demokratycznej legitymizacji głowy państwa, będą stanowić swoisty krytyczny punkt (ang. critical juncture), który może prowadzić do nasilenia się tureckich problemów z demokracją. Będzie to wynikać $z$ uwarunkowań politycznych, $w$ jakich zostało przyjęte i funkcjonuje nowe prawo, jak również problemów systemowych istniejących w Turcji, które nie gwarantują zrównoważenia wzmocnionej pozycji głowy państwa jako organu władzy wykonawczej.

W pierwszej części artykułu zarysowana zostanie procedura wyborów prezydenckich - przed zmianami i po ich wprowadzeniu. W dalszej kolejności przeprowadzona zostanie analiza czynników - formalnych i politycznych, które są istotne z punktu widzenia odpowiedzi na pytanie o znaczenie nowych unormowań wyboru prezydenta dla demokratyzacji. Będzie to wymagać analizy treści aktów prawnych ze wskazaniem na elementy funkcjonalne i dysfunkcjonalne dla demokratycznego charakteru systemu politycznego oraz wykorzystania elementów analizy decyzyjnej - tj. wzięcia pod uwagę czynników stojących za decyzjami o zmianie prawa wyborczego oraz wyborze interpretacji rezultatów zmiany.

\section{Zarys procedury wyborczej na urząd prezydenta Turcji}

W konstytucji tureckiej z 1982 r. procedura wyboru prezydenta została uproszczona w porównaniu z zasadami przyjętymi przez konstytucję z $1961 \mathrm{r}$. Na mocy art. 101-102 ustawy zasadniczej z 1982 r. Wielkie Zgromadzenie Narodowe Turcji wybierało do niedawna prezydenta na okres siedmiu lat - spośród parlamentarzystów oraz obywateli tureckich, którym przysługuje bierne prawo wyborcze. Wszyscy oni musieli legitymować się wyższym wykształceniem i mieć ukończone 40 lat. 
Wystawienie kandydata spoza parlamentu było możliwe na pisemny wniosek co najmniej 1/5 wszystkich członków parlamentu. Okres pomiędzy przedstawieniem prezydium Zgromadzenia kandydatur na stanowisko prezydenta a końcem wyborów wynosił 30 dni. Kandydat na urząd prezydenta, aby zostać wybranym, musiał uzyskać w głosowaniu tajnym 2/3 głosów ogólnej liczby deputowanych. Jeśli w ciągu dwóch tur głosowania, odbywających się w odstępie co najmniej trzech dni, nikt nie uzyskał wymaganej większości, przeprowadzano trzecią turę, w której wymagana była bezwzględna większość głosów całkowitej liczby deputowanych. Jeśli i trzecia tura nie przynosiła rozstrzygnięcia, odbywała się tura czwarta, w której brało udział dwóch kandydatów z najlepszymi wynikami z tury trzeciej. Jeśli spośród nich nie udało się wybrać prezydenta bezwzględną większością głosów, wtedy następowało rozwiązanie parlamentu i nowe wybory. Możliwość takiej sytuacji zmuszała deputowanych do szukania porozumienia.

Nikt nie mógł zostać wybrany ponownie na ten urząd. Od prezydenta wymagana była neutralność, co wiązało się, poza złożeniem mandatu deputowanego w przypadku jego sprawowania, z zerwaniem kontaktów ze swoją partią. Wraz z objęciem urzędu prezydent składał przysięgę przed Zgromadzeniem Narodowym (art. 103 konstytucji). W przypadku choroby lub wyjazdu zagranicznego prezydenta bądź w razie opróżnienia urzędu z powodu śmierci, ustąpienia lub innej przyczyny - do wyboru nowej głowy państwa był on zastępowany przez przewodniczącego Zgromadzenia (art. 106 konstytucji). ${ }^{6}$

Zasady nowego prawa wyborczego na urząd prezydenta Turcji zawarte zostały w konstytucji (przede wszystkim art. 101-103 oraz art. 67) i rozwinięte w ustawie o wyborach prezydenta oraz wielokrotnie zmienianej ustawie o podstawowych regulacjach wyborczych i rejestracji wyborców z 1961 r. ${ }^{7}$ Prezydent jest wybierany nadal spośród parlamentarzystów, którzy ukończyli 40 lat i mają wyższe wykształcenie lub spośród spełniających powyższe warunki obywateli tureckich, którym przysługuje bierne prawo wyborcze do parlamentu. Zasadnicza różnica tkwi w tym, że jest on wybierany przez naród, a nie deputowanych. Stąd też w grę zaczęły wchodzić przepisy wspomnianej ustawy o podstawowych regulacjach wyborczych i rejestracji wyborców. Czynne prawo wyborcze w wyborach prezydenckich mają obywatele Turcji, którzy ukończyli 18 lat. Nie przysługuje ono jednak, tak jak w przypadku

6 Türkiye Cumhuriyeti Anayasası, Kanun No. 2709, Kabul Tarihi 7.11.1982 (Resmi Gazete, 9 Kasım 1982, No. 17863), www.tbmm.gov.tr/anayasa.htm (data dostępu: 10.02 .2007 r.); por. A. Ławniczak, Prawo wyborcze na urząd prezydenta w Turcji, (w:) S. Grabowska, R. Grabowski (red.), Prawo wyborcze na urząd prezydenta w państwach europejskich, Warszawa 2006, s. 271-281; A. Szymański, Prezydent w systemie politycznym Republiki Turcji: na tle aktualnej debaty ustrojowej, (w:) T. Mołdawa, J. Szymanek (red.), Parlament. Prezydent. Rząd. Zagadnienia konstytucyjne wybranych państw, Warszawa 2008, s. 134-135.

$7 \quad$ Wszystkie aktualne przepisy dotyczące wyboru prezydenta w Turcji za: Konstytucja Republiki Tureckiej, tłum. K. Wojciechowska-Litwinek, D. Haftka-Işık, K. Stanek, Ö. Emiroğlu, Warszawa 2013; Cumhurbaskani Seçimi Kanunu..., op. cit., loc. cit.; Seçimlerin Temel Hükümleri ve Seçmen Kütükleri Hakkinda Kanun No. 298, Kabul Tarihi 26.4.1961 (Resmi Gazete, 2 Mayıs 1961, No. 10796), www.mevzuat.gov.tr/MevzuatMetin/1.4.298.doc (data dostępu: 10.02.2015 r.). 
wyborów parlamentarnych, szeregowcom oraz podoficerom pełniącym służbę, studentom uczelni wojskowych oraz osobom skazanym na podstawie pełnomocnego wyroku sądu i przebywającym w zakładach karnych, z wyjątkiem osób skazanych za nieumyślne przestępstwo (w takim przypadku głosowanie w zakładzie karnym odbywa się pod kierunkiem i nadzorem uprawnionego sędziego). Istnieje obowiązek wyborczy (w praktyce nie zawsze egzekwowany, podobnie jak w przypadku innych wyborów).

W maju 2012 r., a więc już po wyborach parlamentarnych z 2011 r., zmienione zostały przepisy wspomnianej ustawy z 1961 r., aby ułatwić głosowanie w wyborach prezydenckich obywatelom Turcji mieszkającym za granicą. Na podstawie zmienionych przepisów tworzony jest specjalnych rejestr wyborczy zawierający nazwiska osób zarejestrowanych w konsulatach i ambasadach tureckich. Jest to oddzielny rejestr od centralnego krajowego rejestru wyborców, związanego z ogólnym internetowym rejestrem mieszkańców, obsługiwany przez Ministerstwo Spraw Wewnętrznych. W około stu zagranicznych punktach wyborczych tworzone są komisje złożone z pięciu członków partii politycznych i urzędników służby cywilnej. Urny wyborcze po głosowaniu są przekazywane do Turcji. Głosy są liczone wraz z krajowymi przez rady wyborcze na poziomie powiatów (tur. ilçe). Wybory za granicą były przeprowadzane między 31 lipca 2014 r. i 3 sierpnia 2014 r. Ich mankamentem był niedopracowany system informacji na temat rejestracji (wiele osób się nie zarejestrowało i nie wzięło ostatecznie udziału w wyborach), co zresztą zgłaszała przed wyborami Organizacja Bezpieczeństwa i Współpracy w Europie (OBWE) ${ }^{8}$

Kadencja prezydenta została skrócona $\mathrm{z}$ siedmiu do pięciu lat i trwa do momentu objęcia urzędu przez nową głowę państwa. Jednak dana osoba może być ponownie wybrana na ten urząd (prezydentem Turcji można więc być dwukrotnie). Kandydatów na urząd prezydenta zarówno z Wielkiego Zgromadzenia Narodowego Turcji, jak i spoza niego może zgłaszać w formie pisemnej co najmniej 20 deputowanych. Partie polityczne, które w wyborach parlamentarnych poprzedzających wybory prezydenckie przekroczyły dziesięcioprocentowy próg wyborczy, mają prawo zgłosić wspólnego kandydata.

Wybory muszą odbyć się w ciągu 60 dni przed upływem kadencji. Taka sama liczba dni obowiązuje w przypadku opróżnienia stanowiska z innego powodu niż kończąca się kadencja. Są przeprowadzane i kontrolowane, jak wybory parlamentarne, przez Naczelną Radę Wyborczą (złożoną z siedmiu członków i czterech zastępców wybieranych przez sądy na sześć lat), rady prowincjonalne i powiatowe (wybierane na dwa lata, te pierwsze złożone z sędziów, drugie - z osób wyłanianych przez partie polityczne i urzędników, poza przewodniczącym - doświadczonym sędzią) oraz komisje wyborcze powoływane na czas wyborów. Partie polityczne mogą 
mieć swoich przedstawicieli w najwyższych organach wyborczych, również w Naczelnej Radzie Wyborczej, lecz bez prawa głosu.

Kampania wyborcza trwa od momentu ustalenia ostatecznej listy kandydatów (11 lipca 2014 r. w przypadku ostatnich wyborów prezydenckich) do wieczora poprzedzającego dzień wyborów. Ogólne zasady prowadzenia kampanii nie różnią się od kampanii parlamentarnej. W marcu 2014 r. odpowiednia zmiana prawna umożliwiła prowadzenie kampanii i przygotowanie materiałów wyborczych $w$ innym języku niż turecki. Specyficznym rozwiązaniem dotyczącym wyborów prezydenckich jest uściślenie kwestii finansowania kampanii. Kandydaci nie mogą otrzymywać środków od partii politycznych, tylko od indywidualnych obywateli, którzy w tym celu otworzą specjalne konto w banku. Niemożliwe są pożyczki. Kandydaci mają obowiązek składania sprawozdań dotyczących środków wydanych na kampanię do Naczelnej Rady Wyborczej (w ciągu dziesięciu dni po ogłoszeniu wyników wyborów), kontrolującej stronę finansową kampanii.

Dany kandydat, aby został wybrany, musi uzyskać bezwzględną liczbę ważnych głosów (co udało się w 2014 r. Erdoğanowi). Jeśli ta większość nie zostanie osiągnięta, to w drugą niedzielę po pierwszej turze przeprowadzana jest druga tura wyborów. W drugiej turze biorą już udział tylko dwaj kandydaci, którzy uzyskali największą liczbę głosów. Wygrywa ten z nich, który uzyska najwięcej ważnie oddanych głosów. W przypadku śmierci lub utraty biernego prawa wyborczego przez jednego z dwóch kandydatów mających brać udział w drugiej turze, jego miejsce zajmuje kandydat, który uzyskał jako kolejny największą liczbę głosów. Co ciekawe, jeśli w drugiej turze zostanie tylko jeden kandydat, głosowanie ma formę referendum. Jeśli uzyska on większość ważnie oddanych głosów, zostaje prezydentem Republiki Turcji.

Osoby kandydujące na urząd prezydenta muszą zrezygnować ze stanowisk rządowych, poza premierem i ministrami. Tak, jak wcześniej, tak i teraz wybrany kandydat musi zrezygnować z członkostwa w partii, aby zachowywać bezstronność. Zrzeka się też mandatu w parlamencie, jeśli został wybrany spośród jego członków. Nadal obejmuje urząd po złożeniu przysięgi przed tureckim parlamentem, zgodnie z artykułem 103 konstytucji. Niezmieniony pozostał też przepis o zastępowaniu w razie konieczności prezydenta przez przewodniczącego parlamentu (art. 106 konstytucji).

\section{Funkcjonalne i dysfunkcjonalne elementy prawa wyborczego ${ }^{9}$}

Niektóre rozwiązania przyjęte w prawie wyborczym na urząd prezydenta Turcji pozwalają na stwierdzenie, że sprzyja ono demokratyzacji państwa. Na podsta- 
wie wymienionych powyżej aktów prawnych ułatwiono, po pierwsze, możliwość udziału w wyborach obywateli tureckich mieszkających za granicą. W ten sposób wzmocniono powszechność elekcji głowy państwa. Jak wspomniano, w praktyce mankamentem był niedopracowany system informacji o rejestracji na potrzeby wyborów, co skutkowało stosunkowo niską partycypacją w 2014 r. Jednak sama OBWE oceniała tę zmianę pozytywnie. Dotyczyło to również umieszczenia w zmienionym prawie wyborczym szczegółowych zasad finansowania kampanii wyborczych, co wzmocniło zasadę przejrzystości. OBWE podkreśliła też ważne dla demokratyzacji dopuszczenie prowadzenia kampanii w różnych językach i dialektach, nie tylko po turecku. Miało to istotne znaczenie dla kandydatów kurdyjskich i mogło stanowić jeden z czynników (choć oczywiście nie najważniejszy), który przyczynił się do uzyskania 9,76\% głosów wyborców przez Selahattina Demirtaşa - kandydata ugrupowań kurdyjskich, na czele z Ludową Partią Demokratyczną (HDP, Halkların Demokratik Partisi). ${ }^{10}$

Jednak istniejące prawo wyborcze zawiera również wiele mankamentów z punktu widzenia demokratycznego charakteru całej procedury wyłaniania prezydenta Turcji. Dotyczy to zarówno ustawy dotyczącej elekcji prezydenta, jak również ogólnych przepisów wyborczych, znajdujących zastosowanie w przypadku wyborów prezydenckich. OBWE wskazuje w tym kontekście na wiele deficytów. $Z$ jednej strony ograniczana jest powszechność zarówno biernego, jak i czynnego prawa wyborczego. W pierwszym przypadku istnieje dożywotni zakaz kandydowania w wyborach więźniów oraz osób, które nie odbyły służby wojskowej (jest to istotny obowiązek, od którego trudno być zwolnionym ze szczególnych względów, jak np. światopogląd). Ponadto możliwość zgłaszania kandydatów przez partie, które przekroczyły dziesięcioprocentowy próg wyborczy ogranicza liczbę osób ubiegających się o urząd prezydenta oraz możliwość kandydowania niezależnym kandydatom. Znalazło to wyraz w wyborach w sierpniu 2014 r., w których wzięło udział trzech kandydatów. Ekmelledin İhsanoğlu teoretycznie brał udział jako bezpartyjny kandydat, ale miał mniejsze lub większe poparcie dwóch głównych partii opozycyjnych - Republikańskiej Partii Ludowej (CHP, Cumhuriyet Halk Partisi) i Partii Ruchu Narodowego (MHP, Milliyetçi Hareket Partisi) oraz później 11 innych ugrupowań. Wymóg wyższego wykształcenia rodzi pewne wątpliwości z punktu widzenia realizacji zasady niedyskryminacji. Należy przypomnieć, że z kolei czynne prawo wyborcze ograniczane jest w przypadku więźniów (z wyjątkami) oraz wojskowych. Nowe przepisy nie tworzą też wystarczających gwarancji do unikania sytuacji pojawiania się w rejestrze wyborców osób nieuprawnionych. Wynika to z częstego braku umieszczania precyzyjnych danych na listach wyborców.

Ponadto, akty prawa wyborczego nie zawierają przepisów, które w wystarczający sposób regulują działanie organów organizujących i przeprowadzających wy- 
bory. Powoduje to w praktyce m.in. brak przejrzystości działania tych organów oraz bezstronności w rozpatrywaniu skarg wyborczych. Zastrzeżenia budzi także brak możliwości odwołania się od decyzji Naczelnej Rady Wyborczej dotyczącej złożonej skargi. Nie jest bowiem pewne, czy prawo obywateli tureckich do składania indywidualnych skarg do Trybunału Konstytucyjnego na naruszanie przez władze publiczne praw i wolności (po wyczerpaniu innych środków), zawarte w art. 148 konstytucji, może być stosowane w powyższym przypadku.

Kolejnym mankamentem jest brak uregulowania w prawie wyborczym na urząd prezydenta kilku kwestii dotyczących kampanii wyborczej, ważnych z punktu widzenia zasad demokracji. Ustawa o wyborach prezydenckich nie zawiera szczegółów dotyczących roli w wyborach partii politycznych, poprzez które organizują się obywatele. Dotyczy to różnych aspektów, chociażby udziału w kampanii poprzez media. Nie jest np. określone w tym kontekście, czy czas antenowy ma być przydzielany poszczególnym osobom czy ugrupowaniom politycznym. Brak precyzyjnego określenia kwestii czasu antenowego prowadził w kampanii prezydenckiej do nadużyć związanych z wykorzystywaniem swojego stanowiska i wpływu na media przez Erdoğana. Rezultatem była trzykrotnie częstsza obecność w wiadomościach telewizyjnych lidera AKP w porównaniu z İhsanoğlu. ${ }^{11}$ To samo dotyczyło kwestii finansowania kampanii. Choć ma się ono odbywać poprzez prywatne wsparcie indywidualnych obywateli, a nie ze środków publicznych, to brak jasnych ograniczeń $\mathrm{w}$ tego typu wsparciu może $\mathrm{w}$ praktyce prowadzić do wyraźnego zróżnicowania w kwotach tego wsparcia, w zależności od możliwości kandydata. Było to widoczne w wyborach z sierpnia 2014 r., w których Erdoğan, pełniąc urząd premiera, otrzymał znacznie większe wsparcie finansowe niż pozostali kandydaci, korzystając również, wbrew przepisom, ze środków publicznych. Jeśli chodzi o darowizny obywateli, polityk AKP otrzymał ponad 24 miliony lir tureckich, podczas gdy İhsanoğlu - 2,1 miliona lir tureckich. ${ }^{12}$

Partie polityczne oraz niezależni kandydaci mają prawo do obserwowania przebiegu wyborów. Jednak nie ma przepisów dotyczących odgrywania roli obserwatorów przez indywidualnych obywateli oraz osoby z zagranicy.

\section{Problem upolitycznienia prawa wyborczego}

Niekorzystnym zjawiskiem w Turcji jest to, iż demokratyzacja przestaje być celem przeprowadzanych reform, a staje się środkiem do osiągania innych celów. Te ostatnie służą bardziej walce politycznej o władzę, co skutkuje coraz większą po-

\footnotetext{
11 Erdoğan wykorzystał nieco ponad 47 tys. jednostek czasu antenowego, İhsanoğlu zaś - około 16 tys. Dane za: Erdoğan medya ile beyin yıkıyor, „Zaman” z 19 sierpnia 2014 r., http://www.zaman.com.tr/gundem_erdogan-medya-ile-beyin-yikiyor_2238375.html (data dostępu: 10.02.2015 r.). 12 Dane z 3 sierpnia 2014 r. za: Turkish Elections. Presidential Elections (August 2014), Rethink Institute, Washing-
ton DC, http://www.rethinkinstitute.org/turkish-elections (data dostępu: 10.02.2015 r.).
} 
laryzacją polityczną i społeczną, a z nią wiąże się nie tylko deficyt demokracji, ale i brak stabilności politycznej państwa. ${ }^{13}$ Upolitycznienie przeprowadzanych reform prawnych jest widoczne również w przypadku zmiany prawa wyborczego na urząd prezydenta Turcji. Odpowiadając na pytanie o wkład tego prawa w demokratyzację państwa tureckiego, należy wskazać, co kierowało politykami AKP, którzy przyjęli nowy system wyboru prezydenta, zaakceptowany później przez społeczeństwo w referendum.

Do tego potrzebne jest wskazanie na okoliczności, w których doszło do powyższej zmiany. W dniu 27 kwietnia 2007 r. odbyła się w tureckim parlamencie pierwsza tura wyborów prezydenckich, nie przynosząc rozstrzygnięcia. Kandydat rządzącej Partii Sprawiedliwości i Rozwoju - ówczesny minister spraw zagranicznych Abdullah Gül nie uzyskał wymaganej większości dwóch trzecich głosów, do czego przyczynił się bojkot wyborów przez opozycję (z nielicznymi wyjątkami). Gül wydawał się mniej kontrowersyjnym kandydatem niż premier Erdoğan. Jednak według świeckich, kemalistowskich elit - przed wszystkim wojska, większości wymiaru sprawiedliwości i biurokracji oraz części inteligencji i mediów - bardzo prawdopodobny wybór na prezydenta kandydata ugrupowania o korzeniach islamskich oznaczałby zagrożenie dla konstytucyjnej zasady laicyzmu. Rządząca partia przejęłaby instytucję, która stoi na straży tej zasady. Ponadto wybór kandydata AKP mógłby prowadzić do odebrania świeckim elitom nie tylko wpływów w obszarze władzy wykonawczej, ale i sądowniczej. Prezydent przyznaje bowiem nominacje na najwyższe stanowiska sędziowskie. W związku z tym sztab generalny wydał późnym wieczorem 27 kwietnia 2007 r. oświadczenie, odebrane jako ostrzeżenie skierowane do rządu, w którym armia wyraziła gotowość obrony świeckiego porządku. Spotkało się ono ze zdecydowanym protestem ze strony AKP. Opozycyjna CHP skierowała z kolei wniosek do Trybunału Konstytucyjnego o unieważnienie pierwszej tury wyborów z powodu braku kworum dwóch trzecich deputowanych. Trybunał, znajdując się pod dużą presją polityczną, 1 maja 2007 r. rozpatrzył ten wniosek pozytywnie, co zostało określone przez premiera Erdoğana jako „strzał w demokrację”. W powtórzonej pierwszej turze wyborów 6 maja 2007 r. nie osiągnięto wymaganego kworum. Zaraz potem Gül zrezygnował z kandydowania. To uniemożliwiło wybór prezydenta przez ówczesny parlament. Wielkie Zgromadzenie Narodowe Turcji wyraziło więc zgodę na przedterminowe wybory parlamentarne, wyznaczone na 22 lipca $2007 \mathrm{r}$. Nowy parlament wybrał Güla na prezydenta w dniu 28 sierpnia 2007 r., w trzeciej turze wyborów. ${ }^{14}$

Turecki parlament przed rozwiązaniem przyjął w dniu 10 maja 2007 r. poprawki do konstytucji, wprowadzające między innymi powszechne wybory prezy-

13 E. Alessandri, Democratization and Europeanization in Turkey after the September 12 Referendum, „Insight Turkey" 2010, nr 4, s. 24.

14 A. Szymański, Konsekwencje kryzysu politycznego w Turcji dla jej europejskich aspiracji, „Biuletyn” (PISM) 2007, nr 22, http://www.pism.pl/files/?id_plik=582 (data dostępu: 13.12.2007 r.). 
denta. Była to głównie inicjatywa AKP, która w ten sposób chciała otworzyć drzwi do wyboru kandydata tej partii przez obywateli i uniknąć wcześniejszej obstrukcji ze strony opozycji. Ówczesny prezydent Ahmet Necdet Sezer zawetował jednak te zmiany dnia 25 maja 2007 r., oficjalnie w obawie o niestabilność państwa będącą rezultatem przeciwstawienia silnego prezydenta premierowi. Weto prezydenckie zostało odrzucone w dniu 31 maja $2007 \mathrm{r}$. W związku z tym Sezer zdecydował 15 czerwca 2007 r. o poddaniu poprawek konstytucyjnych pod referendum, które odbyło się w październiku 2007 r. $^{15}$

Tak więc rząd AKP nie kierował się przy dążeniu do wprowadzania powszechnych wyborów prezydenta chęcią uczynienia postępów w demokratyzacji. Był to czas, kiedy tempo tureckich reform demokratycznych wyraźnie osłabło. Partia Sprawiedliwości i Rozwoju nie miała na uwadze w pierwszej kolejności wzmocnienia demokratycznej legitymacji prezydenta (choć oficjalnie wpisywano tę zmianę $\mathrm{w}$ proces demokratyzacji), ale interes polityczny, związany z chęcią przejęcia kolejnego ważnego urzędu w państwie. Bardzo dobre rezultaty uzyskane przez AKP w wyborach parlamentarnych w lipcu $2007 \mathrm{r}$. pozwalały na przypuszczenie, że to ich kandydat może uzyskać największe poparcie w walce o urząd prezydenta Turcji i tym samym uniknie impasu i perturbacji politycznych, które mogłyby się powtórzyć przy utrzymaniu wyboru głowy państwa przez parlament.

Odrębną kwestią, wskazującą na inne niż demokratyzacja pobudki kierujące działaniami AKP było (i jest) wykorzystywanie nowego prawa wyborczego na urząd prezydenta, przede wszystkim wprowadzenia wyborów powszechnych, do uzasadniania szerszego projektu politycznego, którego realizacja może doprowadzić do nasilenia się tendencji autorytarnych w Turcji. Chodzi tutaj o dążenie Erdoğana i wielu polityków AKP do wprowadzenia systemu prezydenckiego, co w praktyce może oznaczać nadmierne wzmocnienie władzy wykonawczej kosztem ustawodawczej i sądowniczej.

Nie są to plany, które pojawiły się wraz z dojściem do władzy AKP. O systemie prezydenckim wielokrotnie dyskutowano $\mathrm{w}$ mediach oraz $\mathrm{w}$ czasie licznych spotkań i konferencji już przed 2002 r. Powstawały nawet projekty reform związanych z tą kwestią, np. w latach 1999-2000 taki projekt na wniosek prezydenta Süleymana Demirela przygotowała Turecka Fundacja Studiów Ekonomicznych i Społecznych (TESEV, Türkiye Ekonomik ve Sosyal Etüdler Vakfi). ${ }^{16}$ Argumentów za wprowadzeniem systemu prezydenckiego, podawanych przez tureckich polityków, uczonych czy publicystów w latach 1999-2007 było wiele. System ten był traktowany przez jego zwolenników za panaceum na bolączki związane z wadliwym funkcjo-

15 Commission Staff Working Document. Turkey 2007 Progress Report, Brussels, 6.11.2007, SEC(2007) 1436, s. 7 , http://ec.europa.eu/enlargement/pdf/key_documents/2007/nov/turkey_progress_reports_en.pdf (data dostępu: 11.12.2007 r.).

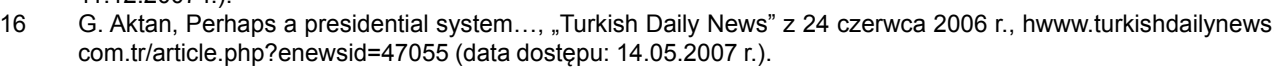


nowaniem systemu parlamentarnego w Turcji. Według nich, wprowadzenie systemu prezydenckiego pozwoliłoby na stabilizację tureckiego systemu politycznego. Po pierwsze, oznaczałoby formowanie rządów technokratycznych, eksperckich oraz silnej prezydenckiej administracji, które byłyby uniezależnione od nacisków partyjnych i bardziej efektywnie rozwiązywały tureckie problemy. Po drugie, likwidowałoby partyjniactwo i fragmentaryzację systemu partyjnego - ugrupowania musiałyby łączyć siły, wspierając jednego z dwóch głównych kandydatów na urząd prezydenta. Wprowadzenie systemu prezydenckiego umożliwiłoby też, według jego zwolenników, wzmocnienie demokratycznego charakteru systemu politycznego Turcji. Prezydent byłby wtedy wybierany z woli narodu. System prezydencki wprowadziłby w ten sposób elementy wspominane powyżej, tj. realny podział władz oraz gwarantowałby większą niezależność parlamentu w sprawowaniu funkcji ustawodawczej oraz kontrolnej. Silny prezydent mógłby zapewnić również lepszą ochronę Republiki i jej zasad - laicyzmu czy nacjonalizmu. ${ }^{17}$

Tak więc wprowadzenie systemu prezydenckiego było ściśle wiązane z powszechnymi wyborami prezydenta - dotyczyły ich dwa wymienione powyżej argumenty, przemawiające za wprowadzeniem tego systemu rządów. Na tym stanowisku stał wyraźnie również Erdoğan. W związku z tym po wprowadzeniu nowego prawa wyborczego zaczęto podkreślać, iż wraz z wprowadzeniem powszechnych wyborów prezydenckich należy podjąć starania w celu, po pierwsze, wykorzystania w pełni istniejących prerogatyw głowy państwa (np. przewodniczenie posiedzeniom Rady Ministrów) oraz, po drugie, powiększenia kompetencji prezydenta, aby jego pozycja ustrojowa była kompatybilna ze sposobem wyboru związanym ze wzmocnioną legitymizacją. Ta druga kwestia jest możliwa dzięki zmianom konstytucyjnym oznaczającym wprowadzenie w Turcji systemu prezydenckiego. Debata na ten temat uległa intensyfikacji na przełomie 2014 i 2015 r., w związku z wyborami parlamentarnymi w czerwcu 2015 r. Ich wyniki były istotne z punktu widzenia możliwości wprowadzenia zmian konstytucyjnych (Erdoğan mówił o potrzebie „,nowej konstytucji”) otwierających drzwi do wprowadzenia w Turcji systemu prezydenckiego. ${ }^{18}$

Choć teoretycznie wymieniona powyżej argumentacja jest nadal aktualna, to jednak analiza wypowiedzi Erdoğana i innych polityków związanych z AKP pozwala na stwierdzenie, że przekonywanie o konieczności efektywnego działania państwa, możliwego dzięki funkcjonowaniu silnej administracji prezydenckiej, zaczęło dominować w debacie o systemie prezydenckim nad argumentacją o postę-

Szerzej zob. Presidential system debates resurfaces, „Turkish Daily News” z 11 marca 2005 r., http://www.turkishdailynews.com.tr/article.php?enewsid=7973 (data dostępu: 15.05.2007 r.); Y. Kanlı, Turkey needs administrative reform, „Turkish Daily News” z 20 października 2006 r., http://www.turkishdailynews.com.tr/article.php?enewsid=57199 (data dostępu: 15.05.2007 r.); G. Aktan, Why a presidential system?, „Turkish Daily News” z 16 maja 2006 r., http://www.turkishdailynews.com.tr/article.php?enewsid=43482 (data dostępu: 15.05 .2007 r.).

S. İdiz, Erdoğan aims to create stronger presidential system, „Al-Monitor” (Turkey Pulse) z 3 lutego 2015 r., www. al-monitor.com/pulse/originals/2015/02/turkey-erdogan-presidential-system-campaign.html\# (data dostępu: 10.02.2015 r.). 
pach w demokratyzacji Turcji. Co więcej, wprowadzenie nowego systemu rządów jest wskazywane nie tylko jako sposób rozwiązania problemów tworzonych przez system parlamentarny, lecz również przez mechanizmy występujące w ustroju demokratycznym. W tym kontekście istotne jest powiązanie stanowiska Erdoğana w kwestii wprowadzenia systemu prezydenckiego z jego negatywnym podejściem do niektórych rozwiązań charakterystycznych dla demokracji. Prezydent Turcji krytykuje przede wszystkim zasadę podziału władz, która ma przecież być wzmacniana dzięki powszechnym wyborom prezydenckim (zamiast elekcji w parlamencie). Jednak według Erdoğana funkcjonowanie tej zasady uniemożliwia efektywne i sprawne działanie struktur państwowych. Przede wszystkim ogranicza działania władzy wykonawczej poprzez uwikłanie w długotrwały proces podejmowania decyzji z udziałem wielu podmiotów (prezydent Turcji narzeka np., że nie może sam decydować, z kim ma współpracować), nadmierną biurokrację oraz procedury legislacyjne i kontrolne (w tym te z główną rolą sądów). ${ }^{19}$ Stąd też konieczne jest wzmocnienie kompetencji egzekutywy - kosztem organów władzy ustawodawczej i sądowniczej.

Krytycy dążeń do wprowadzenia systemu prezydenckiego twierdzą, że może to doprowadzić do autorytarnych czy dyktatorskich rządów prezydenta (,,sułtanatu”) poprzez dekrety automatycznie akceptowane przez słaby parlament. ${ }^{20}$ Niezależnie od tego, czy taki scenariusz zostanie zrealizowany, wprowadzenie systemu prezydenckiego ,a la AKP”, czy może raczej ,a la Erdoğan” może w praktyce oznaczać znaczne osłabienie zasady podziału władz oraz systemu hamulców i równowagi w stosunku do władzy wykonawczej. ${ }^{21}$ Jest to odzwierciedlone w działaniach rządu AKP od 2010 r., o których będzie mowa szerzej poniżej.

Zgodnie z wypowiedziami Erdoğana i części polityków AKP wprowadzenie systemu prezydenckiego w pełni - pierwszy bardzo istotny krok uczyniono wraz ze zmianą prawa wyborczego - nie musi więc oznaczać wzmocnienia ustroju demokratycznego. Paradoksalnie, bardziej demokratyczna legitymizacja głowy państwa może otworzyć drzwi do nadania autorytarnego charakteru tureckiego systemu politycznego.

\section{Problemy systemowe w procesie demokratyzacji}

Powyższy scenariusz jest możliwy z uwagi na uwarunkowania systemowe istniejące w Turcji, stanowiące część zasadniczych problemów w procesie demo-

\footnotetext{
19 H. Hayatsever, Separation of powers an obstacle, says Erdoğan, „Hurriyet Daily News” z 18 grudnia 2012 r., www.hurriyetdailynews.com/separation-of-powers-an-obstacle-says-erdogan .aspx ?pagelD=238\&nid=37052 (data dostępu: 28.12.2012 r.).

20 Cumhurbaşkanı Erdoğan'dan başkanlık sistemi açıklaması, „Radikal” z 29 stycznia 2015 r., www.radikal.com.tr/ politika/cumhurbaskani_erdogandan_baskanlik_sistemi_aciklamasi-1282893 (data dostępu: 10.02 .2015 r.).

21 M. Yetkin, Turkey's future: Strong president or balanced democracy?, „Hurriyet Daily News” z 7 lipca 2014 r., www.hurriyetdailynews.com/turkeys-future-strong-president-or-balanced-democracy.aspx?pagelD=449\&nID= 68746\&NewsCatID=409 (data dostępu: 18.08.2014 r.).
} 
kratyzacji. Niewystarczające są bowiem w tym państwie czynniki, które mogłyby równoważyć wzmocnioną pozycję prezydenta. Po pierwsze, silna wykonawcza władza centralna nie jest równoważona przez regionalne czy lokalne organy władzy. W Turcji istnieje scentralizowana struktura państwa związana z tradycyjnym modelem silnego państwa. ${ }^{22}$ Nie pozwala ona na funkcjonowanie nawet prawdziwego samorządu. Istnieją wybierane w powszechnych wyborach władze lokalne na różnych poziomach, ale są one kontrolowane przez administrację centralną. Co więcej - na poziomach prowincji i powiatów działają obok organów wybieranych bezpośrednio odpowiednio prefekci i naczelnicy mianowani przez władze centralne. Jedynie municypalne jednostki administracyjne i obszary wiejskie wykonują prawie wyłącznie zadania samorządowe. Wyższe jednostki realizują zadania samodzielnie jedynie w wybranych dziedzinach. ${ }^{23}$

Po drugie, z tradycyjnym modelem silnego państwa i jego elit wiążą się autorytarne tendencje odzwierciedlane w tureckiej praktyce politycznej. Stanowią one od dawna problem kultury politycznej w Turcji (nie jest to więc cecha charakterystyczna rządów AKP). ${ }^{24}$ Tendencje te zmierzają przede wszystkim w kierunku wspomnianego wzmocnienia władzy wykonawczej kosztem ustawodawczej i sądowniczej oraz specyficznego modelu silnego przywództwa politycznego. W obu przypadkach osłabiane są znacznie podział władz oraz system hamulców i równowagi.

Istnieje wyraźne dążenie AKP do konsolidacji władzy w swoich rękach. Przejęła ona wszystkie ważniejsze urzędy w państwie. Jednocześnie działania rządu poprzez inicjatywy ustawodawcze, które potem są akceptowane w parlamencie w postaci zmian regulacji prawnych i które są też aprobowane przez prezydenta, ${ }^{25}$ zmierzają w kierunku wzmocnienia policji oraz władzy wykonawczej, przede wszystkim kosztem władzy sądowniczej. Dotyczy to między innymi Ministra Sprawiedliwości. Ma to miejsce szczególnie w przypadkach nominowania osób na najwyższe stanowiska sądownicze (np. w Najwyższej Radzie Sędziów i Prokuratorów), aby kontrolować działania organów sądowniczych oraz wyłączania lub ograniczania działania organów sądowniczych i prokuratury. Ten drugi aspekt przewidują np. zmiany w ustawie o Internecie, zwiększające uprawnienia Prezydium ds. Telekomunikacji i Komunikacji lub poprawki do regulacji dotyczące Narodowej Agencji Bezpieczeństwa, ograniczające odpowiedzialność przed sądem agentów. ${ }^{26}$ Tego rodzaju działania

22 Szerzej zob. A. Szymański, Model państwa w Republice Turcji, (w:) A. Lisowska, A. W. Jabłoński (red.), Państwo w procesach przemian. Teoria i praktyka, Toruń 2009, s. 188-198.

23 A. Szymański, System konstytucyjny Turcji, op.cit., s. 90-94; A. Güney, A.A. Çelenk, Europeanization and the dilemma of decentralization: centre-local relations in Turkey, „Journal of Balkan and Near Eastern Studies” 2010, nr 3, s. 241-257.

24 L. M. McLaren, Constructing Democracy in Southern Europe. A comparative analysis of Italy, Spain and Turkey, London, New York 2008, s. 260.

25 Wyjątki istniały w czasie kadencji prezydenta Güla. Ponadto akceptacja niektórych aktów prawnych była połączona z zastrzeżeniem, że dany dokument należy poprawić. etdailynews.com/turkish-parliament-approves-controversial-intel-bill.aspx?pageID=238\&n ID=65214\&NewsCa$\mathrm{tID}=338$ (data dostępu: 17.04.2014 r.). 
rządu tureckiego rozpoczęły się od zmian konstytucyjnych w 2010 r. (które w wielu aspektach miały jednak charakter demokratyczny) i były kontynuowane w kolejnych latach w pakietach reform dotyczących władzy sądowniczej. ${ }^{27}$ Widoczne jest więc to, że krytyczne podejście do zasady podziału władz, wyrażane prze Erdoğana, ma wpływ na działania rządu AKP.

Określonemu modelowi państwa towarzyszy silne przywództwo. Rządy AKP, podobnie jak rządy konserwatywnej centroprawicy w latach osiemdziesiątych i na początku lat dziewięćdziesiątych XX w., cechuje charakterystyczny model podejmowania decyzji. Zarówno premier, później prezydent Turgut Özal, jak i Erdoğan to silni, charyzmatyczni liderzy, którzy podejmowali decyzje samodzielnie lub po konsultacji z wąskim gronem doradców, ministrów lub członków partii. ${ }^{28}$ Te wąskie kręgi elit państwowych biorących udział w procesie podejmowania decyzji w obu przypadkach zmniejszały się w miarę upływu czasu.

Po trzecie, wiele do życzenia pozostawia w Turcji zasada państwa prawa. Wspominano powyżej, że ważnym czynnikiem równoważącym wzmocnienie pozycji władzy wykonawczej, będące rezultatem wprowadzenia wyborów powszechnych, jest działalność sądów, w tym ich funkcja kontrolna. Rząd AKP dąży jednak do ograniczenia możliwości działania organów sądowych, z Trybunałem Konstytucyjnym na czele, w czym ponownie ujawnia się niechęć polityków tej partii do zasad podziału władz oraz hamulców i równowagi. Nie chodzi w tym miejscu tylko o wspomniane zwiększanie kompetencji władzy wykonawczej w kwestii nominacji na stanowiska w organach sądowniczych czy nawet o działania zmierzające do ograniczania kompetencji tych organów w stosunku do niektórych instytucji. Zauważalna jest także tendencja do nieuznawania wyroków i orzeczeń sądów oraz podważania wiarygodności organów sądowych przez polityków AKP. W pierwszym przypadku charakterystycznym zjawiskiem jest np. kontynuowanie realizacji dużych publicznych przedsięwzięć infrastrukturalnych pomimo wyroku sądu, zgodnie z którym prace powinny być przerwane. W drugim przypadku podważa się wiarygodność naczelnych organów sądowniczych. Najlepszym przykładem jest działalność Trybunału Konstytucyjnego, którego orzeczenia, gdy są niekorzystne dla rządzącej partii, są negowane. AKP wskazuje w takim przypadku na polityczne, a nie merytoryczne motywy działania tej instytucji. ${ }^{29}$ Jest to niebezpieczne zjawisko, gdyż w gruncie rzeczy dąży się do cofnięcia Turcji do okresu sprzed 1961 r. (w tym roku wprowadzono do nowej ustawy zasadniczej Trybunał Konstytucyjny) i pozbawienia systemu politycznego niezależnej kontroli konstytucyjności aktów prawnych.

27 S. Yazıcı, Turkey's Constitutional Amendments: Between the status quo and Limited Democratic Reforms, „Insight Turkey" 2010, nr 2, s. 1-10.

28 M. Heper, Islam, Conservatism and Democracy in Turkey: Comparing Turgut Özal and Recep Tayyip Erdoğan, „Insight Turkey” 2013, nr 2, s. 145.

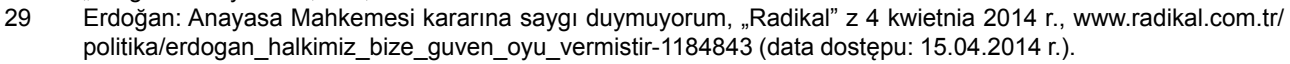




\section{Konkluzje}

Na początku niniejszego artykułu autor postawił pytanie, czy przyjęcie nowego prawa wyborczego, a przede wszystkim wprowadzenie powszechnych wyborów prezydenta, przyczyni się do demokratyzacji państwa tureckiego. Niniejsza analiza potwierdza hipotezę, iż aktualne przepisy, pomimo wzmocnienia demokratycznej legitymizacji głowy państwa oraz usunięcia kilku wcześniej istniejących deficytów w kontekście demokratyzacji, mogą stanowić „krytyczny punkt”, który będzie prowadzić do nasilenia się tendencji autorytarnych w systemie politycznym Turcji. Za taką sytuacją przemawiają okoliczności, w których został przyjęty nowy system wyboru głowy państwa oraz łączenie przez polityków związanych z Partią Sprawiedliwości i Rozwoju wyborów powszechnych prezydenta z koniecznością wprowadzenia systemu prezydenckiego ,a la AKP”. Te kwestie wskazują, że intencją tego ugrupowania jest raczej realizowanie interesów politycznych, a nie dążenie do demokratyzacji państwa. W rezultacie, paradoksalnie, teoretycznie bardziej demokratyczny system wyboru prezydenta może otworzyć drzwi do mniej demokratycznego systemu politycznego. Wprowadzenie systemu prezydenckiego w Turcji (jako dalsza konsekwencja wzmocnienia pozycji prezydenta dzięki wyborom powszechnym) w praktyce będzie bowiem oznaczać zbyt silną władzę wykonawczą, która nie może być wystarczająco równoważona przez inne instytucje polityczne - w ramach władzy ustawodawczej i sądowniczej. Scentralizowany model silnego państwa, dążenia tureckich polityków do nadmiernego wzmacniania władzy wykonawczej, stanowiące tradycyjny dylemat kultury politycznej Turcji oraz problemy z przestrzeganiem państwa prawa nie pozwalają bowiem na funkcjonowanie efektywnych hamulców dla centralnej władzy wykonawczej, występujących np. w USA, tj. stosunkowo silnych władz regionalnych i lokalnych oraz zasad podziału władz i kontroli sądowej.

\section{BIBLIOGRAFIA}

Aktan G., Perhaps a presidential system..., „Turkish Daily News” z 24 czerwca 2006 r., http://www.turkishdailynews.com.tr/article.php?enewsid $=47055$

Aktan G., Why a presidential system? „Turkish Daily News” z 16 maja 2006 r., http://www.turkishdailynews.com.tr/article.php?enewsid $=43482$

Alessandri E., Democratization and Europeanization in Turkey after the September 12 Referendum, „Insight Turkey” 2010, nr 4

Commission Staff Working Document. Turkey 2007 Progress Report, Brussels, 6.11.2007, SEC(2007) 1436, http://ec.europa.eu/enlargement/pdf/key_documents/ 2007/nov/ turkey_progress_reports_en.pdf

Cumhurbaşkanı Erdoğan'dan başkanlık sistemi açıklaması, „Radikal” z 29 stycznia 2015 r., www.radikal.com.tr/politika/cumhurbaskani_erdogandan_baskanlik_sistemi_aciklamasi-1282893 
Cumhurbaskanı Seçimi Kanunu, Kanun No. 6271, Kabul Tarihi 19/1/2012 (Resmi Gazete, 26 Ocak 2012, No. 28185), http://ilo.org/dyn/natlex/docs/SERIAL/91819/106649/F1826753979/91819. pdf

Erdoğan: Anayasa Mahkemesi kararına saygı duymuyorum, „Radikal” z 4 kwietnia 2014 r., www.radikal.com.tr/politika/erdogan_halkimiz_bize_guven_oyu_vermistir-1184843

Erdoğan medya ile beyin yıkıyor, „Zaman” z 19 sierpnia 2014 r., http://www.zaman.com.tr/gundem_erdogan-medya-ile-beyin-yikiyor_2238375.html

Güney A., Çelenk A.A., Europeanization and the dilemma of decentralization: centre-local relations in Turkey, „Journal of Balkan and Near Eastern Studies” 2010, nr 3

Hayatsever H., Separation of powers an obstacle, says Erdoğan, „Hurriyet Daily News” z 18 grudnia 2012 r., www.hurriyetdailynews.com/separation-of-powers-an-obstacle-says-erdogan. aspx?pageID $=238 \&$ nid $=37052$

Heper M., Islam, Conservatism and Democracy in Turkey: Comparing Turgut Özal and Recep Tayyip Erdoğan, „Insight Turkey” 2013, nr 2

İdiz S., Erdoğan aims to create stronger presidential system, „Al-Monitor” (Turkey Pulse) z 3 lutego 2015 r., www.al-monitor.com/pulse/originals/2015/02/turkey-erdogan-presidential-systemcampaign.html\#

Kanlı Y., Turkey needs administrative reform, „Turkish Daily News” z 20 października 2006 r., http:// www.turkishdailynews.com.tr/article.php?enewsid=57199

Konstytucja Republiki Tureckiej, tłum. Karolina Wojciechowska-Litwinek, Dorota Haftka-Işık, Kamila Stanek, Öztürk Emiroğlu, Warszawa 2013

Ławniczak A., Prawo wyborcze na urząd prezydenta w Turcji, (w:) S. Grabowska, R. Grabowski (red.), Prawo wyborcze na urząd prezydenta w państwach europejskich, Warszawa 2006

McLaren L. M., Constructing Democracy in Southern Europe. A comparative analysis of Italy, Spain and Turkey, London, New York 2008

Presidential system debates resurfaces, „Turkish Daily News” z 11 marca 2005 r., http://www.turkishdailynews.com.tr/article.php?enewsid=7973

Pułło A., System prezydencki, (w:) M. Domagała (red.), Konstytucyjne systemy rządów, Warszawa 1997

Republic of Turkey. Presidential Election 10 August 2014, OSCE/ODIHR Needs Assessment Mission Report 7-9 May 2014, Warsaw, 3 June 2014, http://www.osce.org/odihr/elections/ turkey/119439?download=true

Seçimlerin Temel Hükümleri ve Seçmen Kütükleri Hakkinda Kanun No. 298, Kabul Tarihi 26.4.1961 (Resmi Gazete, 2 May1s 1961, No. 10796), www.mevzuat.gov.tr/MevzuatMetin/1.4.298.doc

Szymański A., Konsekwencje kryzysu politycznego w Turcji dla jej europejskich aspiracji, „Biuletyn” (PISM) 2007, nr 22, http://www.pism.pl/files/?id_plik=582

Szymański A., Model państwa w Republice Turcji, (w:) A. Lisowska, A. W. Jabłoński (red.), Państwo w procesach przemian. Teoria i praktyka, Toruń 2009

Szymański A., Prezydent w systemie politycznym Republiki Turcji: na tle aktualnej debaty ustrojowej, (w:) T. Mołdawa, J. Szymanek (red.), Parlament. Prezydent. Rząd. Zagadnienia konstytucyjne wybranych państw, Warszawa 2008 


\section{Adam Szymański}

Szymański A., System konstytucyjny Turcji, Warszawa 2006

Turkish Parliament approves controversial intel bill, „Hurriyet Daily News” z 17 kwietnia 2014 r., www.hurriyetdailynews.com/turkish-parliament-approves-controversial-intel-bill.aspx?page$\mathrm{ID}=238 \& n \mathrm{ID}=65214 \&$ NewsCatID $=338$

Türkiye Cumhuriyeti Anayasas1, Kanun No. 2709, Kabul Tarihi 7.11.1982 (Resmi Gazete, 9 Kasım 1982, No. 17863), www.tbmm.gov.tr/anayasa.htm

Yazıc1 S., Turkey's Constitutional Amendments: Between the status quo and Limited Democratic Reforms, ,Insight Turkey” 2010, nr 2

Yetkin M., Turkey's future: Strong president or balanced democracy?, „Hurriyet Daily News” z 7 lipca 2014 r., www.hurriyetdailynews.com/turkeys-future-strong-president-or-balanced-democracy. aspx?pageID $=449 \& n I D=68746 \&$ NewsCatID $=409$ 


\section{CHANGE OF PRESIDENTIAL ELECTION LAW IN TURKEY - PROGRESS IN THE DEMOCRATIZATION PROCESS?}

The adoption of the new presidential election system in Turkey has strengthened the democratic legitimacy of the head of state, by virtue of the presidency now being determined by popular vote. The new law, however, has many democratic deficits. Moreover, the circumstances of its adoption as well as coupling it with the introduction of a particular type of presidential system, tends to indicate that the intentions of the AKP leaders have less to do with the willingness to democratize the country than with political interests. Paradoxically, as a result, a theoretically more democratic presidential election law can open the door for the enhancement of authoritarian tendencies in the Turkish state. One consequence of introducing the presidential system to strengthen the president's office by way of popular vote, is that it can create too strong an executive power which is not sufficiently balanced by other institutions forming the Turkish political system - both nationally and at regional/local level.

Keywords: president, election law, elections in Turkey, democratization, presidential system, politicisation

Słowa kluczowe: prezydent, prawo wyborcze, wybory w Turcji, demokratyzacja, system prezydencki, upolitycznienie 